\title{
PKM PERAN KOPERASI USAHA TANI DALAM MENINGKATKAN HASIL PERTANIAN DI KELURAHAN TALETE
}

\author{
Agustien Cherly Wereh \\ Universitas Negeri Manado \\ agustien.wereh@unima.ac.id
}

\begin{abstract}
Abstrak
Koperasi adalah badan usaha yang beranggotakan orang seorang atau badan hukum koperasi dengan berlandaskan kegiatannya berdasarkan prinsip koperasi sekaligus sebagai gerakan ekonomi rakyat yang berdasarkan atas asas kekeluargaan. ( Pasal 1 ayat (1) UU No.25 Tahun 1992). Kata "gerakan ekonomi rakyat" mengindikasikan bahwa koperasi adalah wadah bagi ekonomi rakyat.

Berangkat dari paradigma ekonomi kerakyatan, yang mengutamakan kepentingan pengembangan ekonomi rakyat, people's economy yang menempati strata bawah dalam "kerucut" perekonomian nasional, maka retribusi sumber daya harus memberikan hak-hak istimewah kepada pelaku usaha kecil, menengah dan koperasi. Pemihakan terhadap upaya pemberdayaan ekonomi kerakyatan diarahkan untuk mempercepat peran koperasi sebagai wadah ekonomi rakyat, yang bertitik tolak dari arahan bahwa pembangunan koperasi sebagai badan usaha dan sekaligus sebagai gerakan ekonomi rakyat yang sehat, tangguh, kuat, mandiri, unggul dan sebagai pelaku ekonomi yang menggalang kemampuan ekonomi rakyat di lingkup ekonomi nasional.
\end{abstract}

Kata kunci :Peran koperasi, pemberdayaan ekonomi kerakyatan 


\section{PENDAHULUAN}

\subsection{Analisis Situasi}

Di tengah-tengah era globalisasi, kehidupan manusia semakin lama semakin baik. Teknologi dan perekonomian di segala bidang pun berkembang semakin pesat, tak terkecuali di bidang pertanian. Namun ironis, di antara kemajuan-kemajuan tersebut masih ditemukan ketertinggalan dalam hal pengelohan teknologi pertanian maupun manajemen modal pada masyarakat kelurahan Talete

Kelurahan Talete sesungguhnya memiliki kekayaan sumber daya alam yang melimpah. Lahan di kelurahan Talete subur dan berpotensi menghasilkan hasil pertanian yang baik. Pengairannyapun berlimpah ruah, terutama saat musim penghujan. Suhu dan cuaca di Desa Raraatean juga sangat baik, dalam arti sudah sesuai untuk bercocok tanam.

Sayangnya kekayaan sumber daya alam yang melimpah tersebut belum dapat dikelola dan dimanfaatkan oleh penduduk sekitar Kelurahan Talete yang mayoritas bermata pencaharian sebagai petani. Petani di Desa Talete hanya mengelola lahan-lahan kecil untuk ditanami seadanya. Air yang berlimpah ruah dari sumber air di bagian atas desa juga belum dapat tersalurkan dengan baik ke sawah-sawah milik petani karena kurangnya alat bantu pengairan. Keterbatasan modal menjadi salah satu faktor penghambat kemajuan pengelolaan pertanian di desa tersebut. Disamping itu, jenis tanaman yang dibudidayakan belum bervariatif dan harga jualnya masih rendah tidak sebanding dengan modal yang mereka keluarkan.

\subsection{Ide Dasar dan Peran Koperasi Usaha Tani dalam meningkatkan hasil pertanian \\ Modal memegang peranan penting} dalam usaha bercocok tanam para petani. Dengan keterbatasan modal, mereka tidak bisa maju dan berbuat banyak untuk memperbaiki ataupun meningkatkan hasil pertanian mereka. Para petani akan kesulitan untuk membeli pupuk, membeli bibit, membeli peralatan pertanian yang dibutuhkan serta mencukupi biaya perawatan tanaman. Sehingga varietas yang dihasilkan sangat terbatas, baik dari segi kualitas maupun kuantitas. Hal tersebut berakibat pada hasil pertanian yang menjadi kurang maksimal, dan petani terjerat hutang kepada rentenir.

Untuk melancarkan jalannya roda perekonomian inilah sangat dibutuhkan sebuah lembaga yang mampu menyediakan pinjaman modal dan mampu menyediakan kebutuhan pertanian yang lengkap serta dapat membantu memasarkan hasil pertanian dengan harga yang layak. Lembaga yang sesuai untuk membantu penyediaan modal demi melancarkan roda perekonomian masyarakat kelurahan Talete salah satunya adalah koperasi.

Koperasi diharapkan mampu menggerakkan roda perekonomian 
masyarakat bertahap dan akhirnya mampu meningkatkan hasil pertanian dan kualitas hidup masyarakatnya. Dalam rangka pelaksanaan demokrasi ekonomi, koperasi harus makin dikembangkan dan ditingkatkan kemampuannya serta dibina dan dikelola secara efisian, karena koperasi merupakan wadah perekonomian yang sesuai dan sangatlah penting dalam menumbuhkan dan mengembangkan potensi ekonomi rakyat serta dalam mewujudkan kehidupan ekonomi yang bercirikan demokratis, kebersaman dan kekeluargaan guna memajukan kesejahteraan anggota pada khususnya dan masyarakat pada umumnya serta ikut membangun tatanan perekonomian nasional dalam rangka mewujudkan masyarakat yang maju, adil dan makmur berdasarkan Pancasila dan Undang-Undang Dasar Negara Repoblik Indonesia Tahun 1945.

\subsection{Permasalahan Mitra}

Adapun persoalan prioritas yang harus segera diselesaikan sebagai berikut:

1. Jenis-jenis kredit apa saja yang dapat diberikan oleh Koperasi Usaha Tani?

2. Bagaimana tata cara atau prosedur pelaksanaan pemberian kredit kepada masyarakat?

3. Bagaimana pengaruh kredit yang diberikan kepada Koperasi Usaha Tani kepada masyarakat?

\section{TARGET DAN LUARAN}

Koperasi memiliki peranan penting dalam kegiatan perekonomian, karena koperasi dinilai mampu memberikan berbagai kelebihan kepada para anggota atau masyarakat yang memanfaatkan keberadaannya. Koperasi sebagai wadah perekonomian rakyat mempunyai fungsi dan peran seperti yang tertuang dalam Pasal 4 Undang-Undang No.25 Tahun 1992.

Adanya bantuan dari Pemerintah tersebut ditujukan agar masyarakat dapat menikmati kemakmuran secara merata dengan tujuan masyararakat yang adil makmur akan juga tercapai dengan melalui pembangunan dibidang ekonomi, misalnya dengan memberikan kredit kepada pihakpihak yang ekonominya masih lemah atau rakyat kecil terutama di daerah pedesaan. Adanya KUT tersebut diharapkan akan mampu menghapus sistem ijon dan tengkulak yang dalam prakteknya sangat merugikan masyarakat pedesaan, karena sistem ijon maupun tengkulak tersebut merupakan pelarian dari masyarakat ekonomi lemah untuk memenuhi kebutuhan hidupnya.

Ketergantungan petani kepada para tengkulak disebabkan oleh keadaan ekonomi para petani tersebut, mereka sering kekurangan modal dalam melakukan usahanya, untuk mengatasi keadaan tersebut, mereka meminjam uang kepada para tengkulak dengan mengijonkan hasil pertaniannya, akibatnya para tengkulak 
yang sekaligus berfungsi sebagai pelepas uang itu, dapat mempermainkan harga barang-barang pertanian sesuai dengan kehendak mereka. Inilah yang mendorong masyarakat untuk mendirikan Koperasi Usaha Tani (KUT) sebagai wadah penyalur kredit di masyarakat pedesaan.

\section{METODE PELAKSANAAN}

\section{Prosedur Kerja dan Metode}

Metode pendekatan dalam kegiatan pengabdian ini akan dilakukan dalam bentuk pelatihan dan/atau bimbingan teknis pembentukan Koperasi Usaha Tani. Tahapan yang akan dilakukan dalam penerapan Ipteks ini adalah sebagai berikut:

\section{Tahap Sosialisasi}

Untuk lancar dan suksesnya program yang direncanakan, terlebih dahulu diawali dengan melakukan koordinasi dengan pihak Mitra yang dilanjutkan dengan penyampaian informasi program kepada seluruh komponen pengurus, pengelola dan pelaku usaha tentang maksud dan tujuan serta hasil yang diharapkan dari pelaksanaan pelatihan dan bimbingan teknis.

\section{Tahap Penyuluhan}

Model pelatihan/bimbingan teknisakan dilakukan dengan metode ceramah dan simulasi terkait dengan penyampaian teori Saluran/Distribusi Pemasaran yang efektif dan efisien. Untuk memperkuat hasil yang diharapkan juga dalam penyuluhan ini berupaya dilakukan praktek langsung dengan pihak mitra. Adapun tahapan pelatihan ini dilakukan dengan urutan proses sebagai berikut:

\section{a. Proses Persiapan}

Proses persiapan dilakukan untuk mempersiapkan tempat pelaksanaan penyuluhan serta narasumber yang berkompeten dalam pelaksanaan pemecahan masalah yang dihadapi oleh mitra usaha.

\section{b. Proses Pelaksanaan.}

Dalam proses pelaksanaan dibagi menjadi dua sesi yakni penyampaian materi oleh narasumber serta dilanjutkan sesi berikut yakni memberikan praktek bagaimana cara mendirikan dan mengelolah koperasi sehingga dapat menjadi wadah penyalur kredit bagi masyarakat pedesaan.

\section{c. Tahap \\ Pembinaan/Pendampingan}

Setelah kegiatan penyuluhan selesai dilaksanakan, kelompok pengusul akan terus melakukan pendampingan kepada para mitra secara berkelanjutan agar mereka lebih mudah mengidentifikasi dan menemukenali berbagai permasalahan yang mungkin timbul serta mendampingi mitra dalam 
mendirikan dan mengelolah Koperasi Usaha Tani.

\subsection{Partisipasi Mitra}

Dalam mendukung kegiatan ini maka dibutuhkan peran aktif dari mitra dalam mendukung kegiatan penyuluhan ini. Peran aktif yang dimaksudkan adalah dukungan kerjasama yang baik dalam mengikuti penyuluhan dan pendampingan dimaksud serta mempunyai komitmen bersama dalam menerapkan pengetahuan dan pengalaman yang didapat melalui penyuluhan dalam rangka terbentuknya Koperasi Usaha Tani (KUT) yang merupakan wadah perekonomian guna memajukan kesejahteraan anggota pada khususnya dan masyarakat pada umunya.

Disamping itu untuk mendukung kegiatan ini secara berkesinambungan maka diharapkan kelompok usaha/mitra perlu mengadakan pertemuan secara berkala mingguan/bulanan untuk mendiskusikan berbagai permasalahan yang mereka temukan

\section{Metode dan Pendekatan}

Metode kegiatan yang akan diterapkan adalah deseminasi dan Pilot Project pemeliharaan babi dalam kandang semi rens. Dalam Pilot Project ini mitra difasilitasi pembuatan semi rens dengan alasan mendasar bahwa secara genetik babi kampung dominan dengan karakteristik liar, sehingga jika ditempatkan dalam kandang yang tertutup (intensif) di samping mengalami cekaman stres yang pada gilirannya akan mengganggu sistem reproduksi. Oleh karena itu diperlukan metode yang sesuai yang dikandangkan dalam kandang semi rens, dimana kandang hanya sebagai tempat berteduh kala hujan atau panas, dan babi dibiarkan bergerak dan beraktivitas secara bebas di halaman kandang yang dipagari dengan luasan tertentu.

\section{Persiapan Kegiatan}

Tahap persiapan ini diawali dengan penyamaan persepsi dan langkah-langkah kerja tim mulai dari pembagian tugas dan tanggungjawab berdasarkan kompetensi masing-masing anggota tim sampai dengan persiapan administrasi dan perangkat pendukung. Selanjutnya mengidentifikasi kembali permasalahan mendasar yang harus dipahami secara bersama sebelum mengawali kegiatan PKM untuk selanjutnya dianalisis kembali faktor-faktor lain yang belum teridentifikasi sebelumnya dan peluang mengatasi permasalahan terutama yang berkaitan dengan masalah masalah menurunnya produksi dan produktivitas induk. Hasil identifikasi tersebut di samping menjadi dasar penyusunan rencana kerja sekaligus sebagai landasan pelaksanaan kegiatan PKM. Persiapan yang lainnya adalah bahan dan alat yang akan digunakan dalam pelaksanaan kegiatan PKM.

\section{Pelaksanaan Kegiatan}

Kegiatan sosialisasi merupakan salah satu tahapan penting dalam menyampaikan hal-hal yang berkaitan dengan program dan kegiatan PKM. Kegiatan sosialisasi lebih 
ditekankan kepada pemberian pemahaman dan pengertian kepada masyarakat tentang pentingnya kegiatan yang akan dilaksanakan ini berkaitan dengan perbaikan ekonomi keluarga maupun bagi pembangunan daerah. Kegiatan tersebut menyangkut transformasi ilmu pengetahuan dan teknologi dalam upaya memecahkan masalah yang dihadapi oleh Mitra. Dalam kegiatan sosialisasi ini akan dijelaskan pula tentang teknologi perkandangan semi rens yang diterapkan kepada masyarakat berkaitan dengan perbaikan produksi dan produktivitas babi lokal.

Selanjutnya, melalui implementasi teknologi perkandangan, mitra dituntun dalam proses aplikasi teknologi perkandangan semi rens. Sebagaimana diuraikan sebelumnya bahwa sistem perkandangan semi rens sangat cocok untuk budidaya babi kampung. Kandang semi rens adalah model kandang semi terbuka sehingga memberi peluang bagi ternak babi kampung melakukan aktivitas sebagaimana lazimnya di alam bebas namun dibatasi ruang gerak dalam lingkaran pagar (kawat dll) sehingga ruang geraknya terbatas. Pentingnya deseminasi sistem perkandangan semi rens juga bertujuan untuk lokalisasi babi kampung karena selama ini babi kampung dibiarkan berkeliaran secara bebas di perkampungan yang tentunya selain menyebarkan kotorannya dalam berbagai tempat yang tentunya selain menjadi sumber penyakit, juga dapat mengganggu tatanan sosial kehidupan masyarakat.

\section{HASIL DAN LUARAN YANG DICAPAI}

\section{A. Waktu Pelaksanaan}

Kegiatan pengabdian ini dilaksanakan pada hari Selasa Tgl. 16 April 2019, di kelurahan Talete kecamatan Tomohon Tengah Selatan Kota Tomohon.

\section{B. Pelaksanaan Kegiatan}

Proses penyajian dilakukan dalam bentuk ceramah, tentang hak \& kewajiban anggota koperasi, siapa saja yang bisa menjadi anggota koperasi serta apa saja yang dimuat dalam Anggaran Dasar \& Anggaran Rumah Tangga dalam suatu koperasi, khususnya Koperasi Usaha Tani

\section{Evaluasi Pelaksanaan}

Pelaksanaan kegiatan pengabdian yang dilakukan pada hari Selasa Tgl 16 April 2019, memiliki kendala waktu dimana masyarakat lebih memilih untuk bekerja dan melaksanakan aktifitas mereka bersama keluarga, sesuai dengan sasaran diharapkan kehadiran para petani tapi karena mereka memiliki waktu kerja bahkan terkadang harus melaksanakan lembur hingga pada ahirnya yang mengikuti kegiatan ini masyarakat umum.

\section{Luaran Yang Dicapai}

Sesuai rencana beberapa capaian yang diperoleh yaitu : 
1. Terbentuknya koperasi Usaha Tani yang memiliki tujuan untuk mensejaterahkan anggotanya secara khusus dan masyarakat secara umum

2. Publikasi ilmiah yang akan diterbitkan melalui jurnal.

3. Terhindarnya para petani dari jeratan rentenir

4. Pemahaman yang lebih utuh mengenai pentingnya koperasi dalam membantu para petani mendapatkan pinjaman modal untuk mengolah lahan pertanian sebelum panen, sehingga mereka tidak lagi meminjam uang pada rentenir.

\section{KESIMPULAN DAN SARAN}

\section{Kesimpulan}

Pelaksanaan kegiatan pengabdian pada masyarakat agar melibatkan masyarakat yang sesuai dengan sasaran dibutuhkan perencanaan yang matang dan melibatkan seluruh perangkat Kelurahan mitra. Kepala kelurahan harus memberikan pemahaman awal tentang rencana dan dampak positif ketika mengikuti.Beberapa kendala dalam pelaksanaan yaitu waktu mulai yang belum tepat waktu, serta kurang siapnya masyarakat ketika memulai kegiatan. Oleh karena itu perlu adanya kegiatan awal mendahului kegiatan utama, sehingga diperoleh hasil yang lebih optimal. Beberapa simpulan dalam pelaksanaan kegiatan ini yaitu :

1. Masih relative banyak masyarakat yang meminjam uang kepada rentenir untuk modal mengelolah lahan pertanian

2. Sebagian besar masyarakat mengelolah lahan pertanian dengan menggunakan alat seadanya \& bibit yang tidak unggul karena keterbatasan modal.

3. Masih terlalu banyak masyarakat yang tanpa sadar terjerumus kepada rentenir yang meminjamkan modal kepada mereka dengan sistem ijon yakni menbayar dengan hasil pertanian dengan harga yang ditentukan oleh rentenir, menyebabkan kerugian kepada petani.

\section{Saran}

1. Setiap warga masyarakat perlu mengetahui pentingnya koperasi dalam membantu setiap anggotanya secara khusus dan masyarakat pada umumnya.

2. Perlu adanya koperasi usaha tani sebagai wadah untuk melindungi kepentingan petani agar tidak terjebak kepada rentenir

3. Perlu adanya kemitraan yang terusmenerus antara perguruan tinggi dengan masyarakat 
Jurnal ABDIMAS, Vol. 12, No. 2, Agustus 2019

ISSN: 1979-0953 | e-ISSN: 2598-6066 